\title{
Surface roughness of uncoated particleboards and its relation with the raw material, adhesive and climatic conditions
}

\author{
A. Rolleri • E. Roffael
}

Received: 6 November 2008 / Published online: 31 July 2009

(C) Springer-Verlag 2009

\begin{abstract}
The effect of raw material, adhesive and climatic conditions on the surface roughness and moisture content of uncoated particleboards was determined. Particleboards made with recycled particles in the surface layer had the roughest surfaces irrespective of the adhesive used. The relationship between equilibrium moisture content and roughness are a complex function of interactions between many variables.
\end{abstract}

\section{Die Interaktion zwischen Rohstoff, Klebe- und Klimabedingungen auf die Rauhigkeit von unbeschichteten Spanplatten}

Zusammenfassung Die Auswirkungen der Rohstoff-, Bindemittel- und Klimabedingungen auf die Oberflächenrauheit und den Feuchtigkeitsgehalt von unbeschichteten Spanplatten wurden ermittelt. Spanplatten aus recycelten Spänen in der Deckschicht wiesen die höchste Rauhigkeit auf unabhängig von dem verwendeten Bindemittel. Die Beziehung zwischen Gleichgewichtsfeuchte und Rauheit ist eine Funktion von komplexen Interaktionen zwischen vielen Parametern.

\footnotetext{
A. Rolleri (汭)

Instituto de Tecnología de Productos Forestales,

Universidad Austral de Chile,

Campus Isla Teja,

567 Casilla, Valdivia, Chile

e-mail: arolleri@uach.cl

E. Roffael

Institut für Holzbiologie und Holztechnologie,

Georg August Universität zu Göttingen,

Büsgenweg 4,

37077 Göttingen, Germany

e-mail: eroffae1@gwdg.de
}

\section{Introduction}

The surface roughness is a function of the raw material properties and technical parameters like: type and amount of resin, press cycle, sanding and moisture content of the boards (Hiziroglu and Graham 1998).

Under different climatic conditions the physical and chemical characteristics of board surfaces may noticeably change depending on, e.g., the wood species of the raw materials used in the boards as well as the binders applied (Roffael 1993). In previous work the relationship between equilibrium moisture content (E.M.C.) and surface average roughness $\left(R_{\mathrm{a}}\right)$ of MDF was studied (Rolleri and Roffael 2007).

The main objective of this study was to evaluate the effect of fresh particles and recycling particles from UF-bonded boards and recycling cork particles on the surface properties of particleboards bonded with an urea-formaldehyde resin (UF-resin) and a tannin-formaldehyde resin (TF-resin) after storage under three climatic conditions $\left(20^{\circ} \mathrm{C} / 30 \%\right.$ relative humidity, $20^{\circ} \mathrm{C} / 65 \%$ relative humidity, and $20^{\circ} \mathrm{C} / 85 \%$ relative humidity).

\section{Materials and methods}

Three layer particleboards were produced using different raw materials in the surface and different binders. The raw materials used for the surfaces of the particleboards were industrially produced fresh particles, recycled particles from industrially produced UF-bonded particleboards and recycled cork particles. For the core layers of the chipboards, industrial produced fresh particles were used in all cases.

The fresh particles for the surface and core layers of the particleboards were supplied by a German particleboard 
company. The particles were a mixture of spruce (Picea abies) and Douglas fir (Pseudotsuga menziesii). The size of the fresh surface particles was between 0.2 and $1.0 \mathrm{~mm}$.

The same company offered $19 \mathrm{~mm}$ uncoated urea-formaldehyde bonded particleboards for the production of recycled surface particles. The recycled particles were produced by means of a dry process in the laboratories of the Institute of Wood Biology and Wood Technology. Therefore, the UF-bonded particleboards were cut into pieces of $5.0 \times 5.0 \mathrm{~cm}^{2}$ and thereafter ground with a special aggregate (Electra industrie). After the grinding process, the recycled particles were screened and classified according to their sizes. Only recycled particles with a size between 0.2 and $1.0 \mathrm{~mm}$ were used for the surface layers of recycled particleboards.
The cork particles were supplied by a German company. The cork particles were also meshed and classified in the range of 0.2 and $1.0 \mathrm{~mm}$.

For the preparation of particleboards, a commercial ureaformaldehyde resin (UF-resin, BASF K 350) and a tanninformaldehyde resin (TF-resin) were used. The fresh and recycled particles were dried to a moisture content (M.C.) of $4 \%$, the cork particles were dried to a moisture content (M.C.) of $2 \%$. Six different variants of particleboards were made maintaining constant the density in all of them; from each type three boards were produced. In Table 1, the conditions of board preparation are compiled.

After production, the particleboards were trimmed to the target dimensions $\left(410 \times 410 \mathrm{~mm}^{2}\right)$ and sanded (grain 120) to the target thickness $(19 \mathrm{~mm})$. Thereafter, the particle-

Table 1 Preparation conditions of the tested boards

Tabelle 1 Herstellungsbedingungen der untersuchten Platten

\begin{tabular}{|c|c|c|c|c|c|c|}
\hline & Variant 1 & Variant 2 & Variant 3 & Variant 4 & Variant 5 & Variant 6 \\
\hline Surface layer & Fresh particles & Fresh particles & Recycled particles & Recycled particles & Cork particles & Cork particles \\
\hline Number of boards & 3 & 3 & 3 & 3 & 3 & 3 \\
\hline Layers & 3 & 3 & 3 & 3 & 3 & 3 \\
\hline Target density & $700 \mathrm{~kg} / \mathrm{m}^{3}$ & $700 \mathrm{~kg} / \mathrm{m}^{3}$ & $700 \mathrm{~kg} / \mathrm{m}^{3}$ & $700 \mathrm{~kg} / \mathrm{m}^{3}$ & $700 \mathrm{~kg} / \mathrm{m}^{3}$ & $700 \mathrm{~kg} / \mathrm{m}^{3}$ \\
\hline Size of the boards & $410 \times 410 \mathrm{~mm}^{2}$ & $410 \times 410 \mathrm{~mm}^{2}$ & $410 \times 410 \mathrm{~mm}^{2}$ & $410 \times 410 \mathrm{~mm}^{2}$ & $410 \times 410 \mathrm{~mm}^{2}$ & $410 \times 410 \mathrm{~mm}^{2}$ \\
\hline $\begin{array}{l}\text { Thickness of } \\
\text { the boards }\end{array}$ & 19 mm (sanded) & 19 mm (sanded) & 19 mm (sanded) & 19 mm (sanded) & $19 \mathrm{~mm}$ (sanded) & 19 mm (sanded) \\
\hline Binder type & $\begin{array}{c}\text { UF-resin, BASF } \\
\text { K } 350(65 \% \text { solids } \\
\text { content })\end{array}$ & $\begin{array}{l}\text { TF-resin }(45 \% \\
\text { solids content) }\end{array}$ & $\begin{array}{c}\text { UF-resin, BASF } \\
\text { K } 350(65 \% \text { solids } \\
\text { content })\end{array}$ & $\begin{array}{l}\text { TF-resin }(45 \% \\
\text { solids content) }\end{array}$ & $\begin{array}{c}\text { UF-resin, BASF } \\
\text { K } 350 \text { (65\% solids } \\
\text { content) }\end{array}$ & $\begin{array}{l}\text { TF-resin }(45 \% \\
\text { solids content) }\end{array}$ \\
\hline Type of tannin & & $\begin{array}{c}\text { Colatan GT } 5 \\
\text { Industria Argentina }\end{array}$ & & $\begin{array}{c}\text { Colatan GT } 5 \\
\text { Industria Argentina }\end{array}$ & & $\begin{array}{l}\text { Colatan GT } 5 \\
\text { Industria Argentina }\end{array}$ \\
\hline Binder level & $\begin{array}{l}\text { Surface layer } 10 \% \\
\text { (solids based on } \\
\text { o.d. particles) } \\
\text { Core layer } 8 \% \\
\text { (solids based on } \\
\text { o.d. particles) }\end{array}$ & $\begin{array}{l}\text { Surface layer } 14 \% \\
\text { (solids based on } \\
\text { o.d. particles) } \\
\text { Core layer } 12 \% \\
\text { (solids based on } \\
\text { o.d. particles) }\end{array}$ & $\begin{array}{l}\text { Surface layer } 10 \% \\
\text { (solids based on } \\
\text { o.d. particles) } \\
\text { Core layer } 8 \% \\
\text { (solids based on } \\
\text { o.d. particles) }\end{array}$ & $\begin{array}{l}\text { Surface layer } 14 \% \\
\text { (solids based on } \\
\text { o.d. particles) } \\
\text { Core layer } 12 \% \\
\text { (solids based on } \\
\text { o.d. particles) }\end{array}$ & $\begin{array}{l}\text { Surface layer } 10 \% \\
\text { (solids based on } \\
\text { o.d. particles) } \\
\text { Core layer } 8 \% \\
\text { (solids based on } \\
\text { o.d. particles) }\end{array}$ & $\begin{array}{l}\text { Surface layer } 8 \% \\
\text { (solids based on } \\
\text { o.d. particles) } \\
\text { Core layer 10\% } \\
\text { (solids based on } \\
\text { o.d. particles) }\end{array}$ \\
\hline Hardener & Ammonium sulfate & & Ammonium sulfate & & Ammonium sulfate & \\
\hline $\begin{array}{l}\text { Added } \\
\text { formaldehyde }\end{array}$ & & $\begin{array}{l}10.5 \% \text { (active } \\
\text { formaldehyde based } \\
\text { on o.d. tannin) }\end{array}$ & & $\begin{array}{l}10.5 \% \text { (active } \\
\text { formaldehyde based } \\
\text { on o.d. tannin) }\end{array}$ & & $\begin{array}{c}\text { Surface layer } 6.5 \% \\
\text { (active formaldehyde } \\
\text { based on o.d. tannin) } \\
\text { Core layer } 8.5 \% \\
\text { (active formaldehyde } \\
\text { based on o.d. tannin) }\end{array}$ \\
\hline Hardener level & $\begin{array}{l}\text { Surface layer } 3.0 \% \\
\text { Ammonium sulfate } \\
\text { (solids based } \\
\text { on o.d. resin) } \\
\text { Core layer } 3.0 \% \\
\text { Ammonium sulfate } \\
\text { (solids based } \\
\text { on o.d. resin) }\end{array}$ & & $\begin{array}{l}\text { Surface layer } 3.0 \% \\
\text { Ammonium sulfate } \\
\text { (solids based } \\
\text { on o.d. resin) } \\
\text { Core layer } 3.0 \% \\
\text { Ammonium sulfate } \\
\text { (solids based } \\
\text { on o.d. resin) }\end{array}$ & & $\begin{array}{c}\text { Surface layer } 3.0 \% \\
\text { Ammonium sulfate } \\
\text { (solids based } \\
\text { on o.d. resin) } \\
\text { Core layer } 3.0 \% \\
\text { Ammonium sulfate } \\
\text { (solids based } \\
\text { on o.d. resin) }\end{array}$ & \\
\hline $\begin{array}{l}\text { Pressing } \\
\text { temperature }\end{array}$ & $190^{\circ} \mathrm{C}$ & $190^{\circ} \mathrm{C}$ & $190^{\circ} \mathrm{C}$ & $190^{\circ} \mathrm{C}$ & $190^{\circ} \mathrm{C}$ & $190^{\circ} \mathrm{C}$ \\
\hline Pressing time & $\begin{array}{l}10 \mathrm{~s} / \mathrm{mm} \text { (exl. } \\
\text { closing time } \\
\text { of the press) }\end{array}$ & $\begin{array}{l}20 \mathrm{~s} / \mathrm{mm} \text { (exl. } \\
\text { closing time } \\
\text { of the press) }\end{array}$ & $\begin{array}{l}10 \mathrm{~s} / \mathrm{mm} \text { (exl. } \\
\text { closing time } \\
\text { of the press) }\end{array}$ & $\begin{array}{l}20 \mathrm{~s} / \mathrm{mm} \text { (exl. } \\
\text { closing time } \\
\text { of the press) }\end{array}$ & $\begin{array}{l}36 \mathrm{~s} / \mathrm{mm} \text { (exl. } \\
\text { closing time } \\
\text { of the press) }\end{array}$ & $\begin{array}{l}45 \mathrm{~s} / \mathrm{mm} \text { (exl. } \\
\text { closing time } \\
\text { of the press) }\end{array}$ \\
\hline
\end{tabular}


boards were conditioned for about four weeks prior to evaluating their surface roughness at the three different climatic conditions $20{ }^{\circ} \mathrm{C} / 30 \%$ relative humidity, $20{ }^{\circ} \mathrm{C} / 65 \%$ relative humidity, and $20^{\circ} \mathrm{C} / 85 \%$ relative humidity.

The surfaces of the boards were characterized under laboratory conditions as described by Rolleri and Roffael (2007).

\section{Results and discussion}

As can be seen from Table 2, the moisture content of all UF- and TF-bonded particleboards increased with increasing relative humidity irrespective of the lignocellulosic raw material and the binder used in making the boards. UFand TF-bonded particleboards made from fresh and recycled particles in the surface layers showed more or less the same rise in moisture content with increasing relative humidity during storage. The equilibrium moisture content of the uncoated UF- and TF-bonded particleboards made using cork particles in the surface layer was however lower than that of UF-particleboards made with fresh and recycled particles in the surface. TF-bonded uncoated particleboards generally showed higher equilibrium moisture content compared to UF-bonded uncoated particleboards.

Moreover, Table 2 also relates the general influence of different climatic conditions to the roughness of uncoated UF- and TF-bonded particleboards. The average roughness $\left(R_{\mathrm{a}}\right)$ of uncoated UF-bonded particleboards made using fresh and recycled particles increased with increasing moisture content. The same tendency also applies to uncoated
TF-bonded particleboards made using recycled particles. Interestingly, cork particles showed a quite different behaviour as no detectable increase in the roughness of the boards due to increase in the moisture content of the boards was measured irrespective of the adhesive used. Table 2 also shows that particleboards made with recycled particles in the surface layer had the highest roughness in the surface (average roughness $\left(R_{\mathrm{a}}\right)$ ) irrespective of the adhesive used.

\subsection{Statistical analysis ANOVA}

The influence of the factors raw material, adhesive, and climatic conditions as well as the interaction between them on the average roughness $\left(R_{\mathrm{a}}\right)$ of the uncoated particleboards was determined. As can be seen from Table 3, only the factor raw material as a single factor has significant influence (0.0018) on the average surface roughness of the uncoated particleboards.

However, statistical analysis showed an interaction between the factors raw material and adhesive (0.0177) on the average roughness $\left(R_{\mathrm{a}}\right)$. There is a significant difference in average roughness $\left(R_{\mathrm{a}}\right)$ between uncoated particleboards made from recycled particles due to changes in the adhesive (UF- or TF-resin). UF-bonded particleboards made from recycled particles in the surface layer showed higher roughness values compared to those made with TF-resin.

According to the ANOVA test, the climatic conditions exert a high influence on the moisture content of the particleboards as a single factor $(<0.0001)$. Other single factors

Table 2 Average roughness $R_{\mathrm{a}}(\mu \mathrm{m})$ and equilibrium moisture content (E.M.C.) (\%) of uncoated UF- and TF-bonded particleboards, made using different raw materials in the surface layers (fresh particles, recycled particles and cork particles) after storage under different climatic conditions $\left(20^{\circ} \mathrm{C} / 30 \%\right.$ relative humidity, $20^{\circ} \mathrm{C} / 65 \%$ relative humidity and $20^{\circ} \mathrm{C} / 85 \%$ relative humidity)

Tabelle 2 Mittlere Rauhigkeitswerte $R_{\mathrm{a}}[\mu \mathrm{m}]$ (ermittelt nach dem Tastschnittverfahren) und Feuchtegehalt (\%) der hergestellten Laborspanplatten in Abhängigkeit vom Deckschichtmaterial (Frischspäne, Recyclingspäne, Recyclingkork), dem Bindemitteltyp (UF-, TF-Harz) und der Klimalagerung der Platten

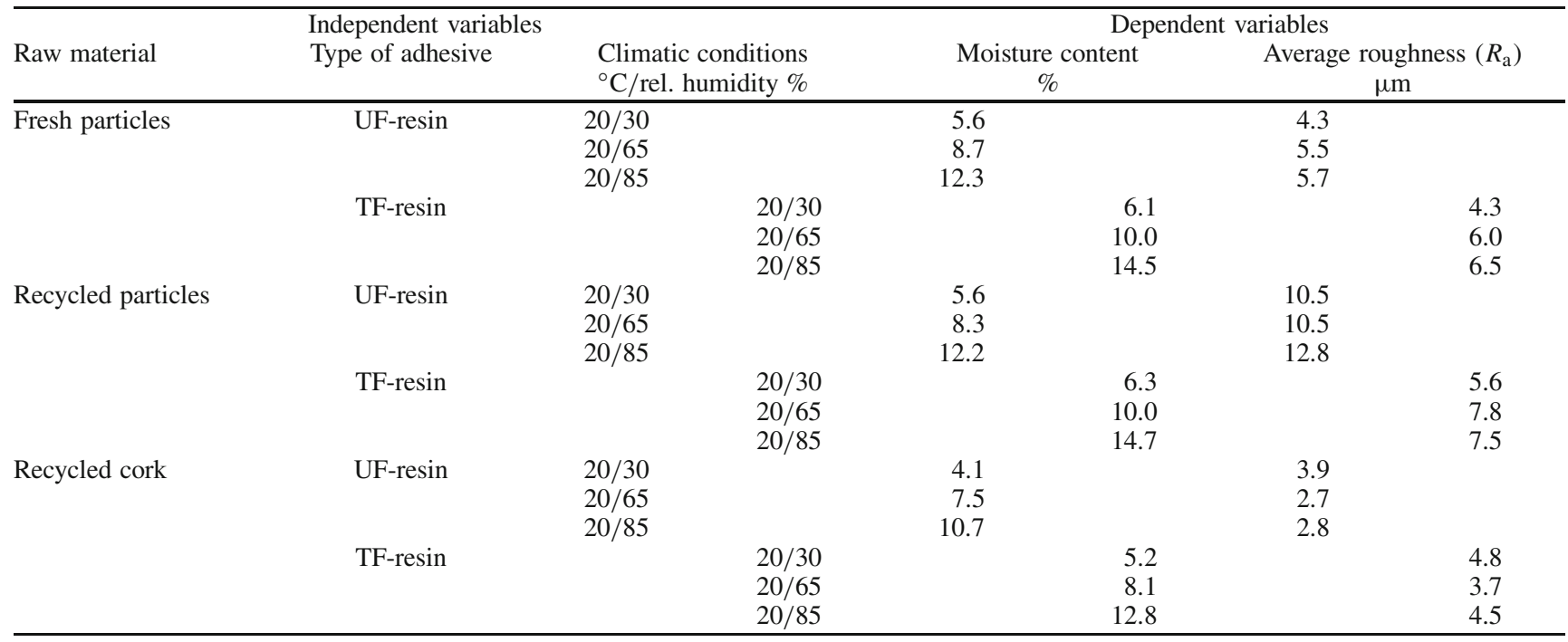


Table 3 Results of the ANOVA analysis, grade of significance expressed as probability under two levels $(0.05 \%$ of probability as significant and $0.01 \%$ of probability as highly significant)

Tabelle 3 Ergebnisse der faktoriellen Analyse mittels Anova-Test und Tukey Honest Significant Difference Test (Irrtumswahrscheinlichkeit 0,05 bzw. $0,01 \%$ )

\begin{tabular}{|c|c|c|c|c|c|c|}
\hline \multirow[b]{2}{*}{$\begin{array}{l}\text { Responses } \\
\text { (dependent variables) }\end{array}$} & \multicolumn{3}{|c|}{$\begin{array}{c}\text { Factors } \\
\text { (independent variables) }\end{array}$} & \multicolumn{3}{|c|}{$\begin{array}{l}\text { Interrelation between factors } \\
\text { (independent variables) }\end{array}$} \\
\hline & Raw material & Adhesive & Climate & $\begin{array}{c}\text { Raw material/ } \\
\text { Adhesive }\end{array}$ & $\begin{array}{l}\text { Raw material/ } \\
\text { Climate }\end{array}$ & $\begin{array}{l}\text { Adhesive/ } \\
\text { Climate }\end{array}$ \\
\hline Average roughness $\left(R_{\mathrm{a}}\right) \mu \mathrm{m}$ & 0.0018 & not significant & not significant & 0.0177 & not significant & not significant \\
\hline Moisture content $(\%)$ & 0.0014 & 0.0005 & $<0.0001$ & not significant & not significant & 0.0246 \\
\hline
\end{tabular}

are the raw material and the adhesive $(0.0005$ and 0.0014 , respectively).

A Tukey's analysis compared the influence of both factors adhesives (UF- and TF-resin) and climate $\left(20^{\circ} \mathrm{C} / 30 \%\right.$ R.H., $20^{\circ} \mathrm{C} / 65 \%$ R.H., and $20^{\circ} \mathrm{C} / 85 \%$ R.H.) on the moisture content of the particleboards. The results reveal that only at $20^{\circ} \mathrm{C} / 85 \%$ R.H. the use of UF- and TF-resin lead to significant differences in the moisture content of the particleboards. The higher moisture content of TF-bonded particleboards may be due to the presence of alkali in TF-resins.

Finally, even though the study was focused on the influence of climatic conditions on surface roughness of particleboards where the average density remained constant, the possible variations in the density profile of the surface layers and the interaction of these with sanding process make the density a very important factor to be considered in future experiences.

\section{Conclusion}

Particleboards made with recycled particles in the surface layer had the highest roughness in the surface average roughness $\left(R_{\mathrm{a}}\right)$ irrespective of the adhesive used.
Interestingly, cork particles showed a quite different behaviour as no detectable increase in the roughness of the boards due to increase in the moisture content of the boards was measured irrespective of the adhesive used.

TF-bonded uncoated particleboards generally showed higher equilibrium moisture content compared to UFbonded uncoated particleboards. This may be due to the alkaline nature of the tannin formaldehyde resins used.

The density and its possible variations must be considered in future since they are influencing roughness parameters.

\section{References}

Hiziroglu S, Graham M (1998) Effect of press closing time and target thickness on surface roughness of particleboard. For Prod J 48(3):50-54

Roffael E (1993) Formaldehyde release from particleboard and other wood based panels. Malay For Rec No 37. ISBN: 983-959215-7

Rolleri A, Roffael E (2007) Influence of different climatic conditions on the roughness of uncoated medium density fiberboards (MDF). Holz Roh- Werkst 65:239-244 